\title{
Sistem Pendukung Keputusan Untuk Mendiagnosa Gizi Buruk Ibu Hamil Menggunakan Metode $\boldsymbol{A H P}$
}

\author{
Nurwati ${ }^{1}$, Fauriatun Helmiah 2 , Dewi Maharani ${ }^{3}$ \\ Program Studi Teknik Komputer, STMIK Royal Kisaran \\ Nurwati763@gmail.com,fahel_mimi@yahoo.com,dewimaharani15@gmail.com
}

\begin{abstract}
In searching and determining decisions can be done by many methods, one of them using the Analytical Hierarchy Process (AHP) method. Analytical Hierarchy Process (AHP) is a decision model developed to describe a complex multi-factor or multi-criteria problem into a representation of a complex problem in a multi-level structure where the first level is an objective, followed by a level of factors, criteria, sub-criteria and so on down to the last level of alternatives. Health is a state of well-being of the body, soul and social that enables everyone to live productively socially and economically. Health care efforts are by way of prevention and prevention of health problems that include examination, treatment and care including the development of pregnant women.
\end{abstract}

Keywords: AHP Method, Pregnant Women, Decision Support System

\begin{abstract}
Abstrak-Dalam mencari dan menentukkan keputusan dapat dilakukan dengan banyak metode, salah satunya menggunakan metode Analytical Hierarchy Process (AHP). Analytical Hierarchy Process (AHP) merupakan suatu model keputusan yang dikembangkan untuk menguraikan masalah multi faktor atau multi kriteria yang kompleks menjadi suatu representasi dari sebuah permasalahan yang kompleks dalam suatu struktur multi level dimana level pertama adalah tujuan, yang diikuti level faktor, kriteria, sub kriteria dan seterusnya ke bawah hingga level terakhir dari alternatif. Kesehatan adalah keadaan sejahtera dari badan, jiwa dan sosial yang memungkinkan setiap orang hidup produktif secara sosial dan ekonomis. Upaya pemeliharaan kesehatan adalah dengan cara penanggulangan dan pencegahan gangguan kesehatan yang meliputi pemeriksaan, pengobatan dan perawatan termasuk perkembangan ibu hamil.
\end{abstract}

Kata Kunci: Metode AHP, Ibu Hamil, Sistem Pendukung Keputusan

\section{PENDAHULUAN}

Dalam mencari dan menentukkan keputusan dapat dilakukan dengan banyak metode, salah satunya menggunakan metode Analytical Hierarchy Process (AHP). Analytical Hierarchy Process (AHP) merupakan suatu model keputusan yang dikembangkan untuk menguraikan masalah multi faktor atau multi kriteria yang kompleks menjadi suatu representasi dari sebuah permasalahan yang kompleks dalam suatu struktur multi level dimana level pertama adalah tujuan, yang diikuti level faktor, kriteria, sub kriteria dan seterusnya ke bawah hingga level terakhir dari alternatif. Kesehatan adalah keadaan sejahtera dari badan, jiwa dan sosial yang memungkinkan setiap orang hidup produktif secara sosial dan ekonomis. Upaya pemeliharaan kesehatan adalah dengan cara penanggulangan dan pencegahan gangguan kesehatan yang meliputi pemeriksaan, pengobatan dan perawatan termasuk perkembangan ibu hamil. Perkembangan ibu hamil merupakan faktor utama untuk melahirkan bayi yang sehat, dalam hal ini ibu 
hamil banyak mengalami gejala-gejala yang tidak diinginkan pada tumbuh kembang janin di dalam kandungan, seperti turunnya berat badan ibu hamil, janin tidak bergerak, janin tidak mengalami perkembangan berat badan dalam kandungan dan masih banyak lainnya. Salah satunya adalah Posyandu Sumber Waras. Karena dengan menggunakan metode AHP diagnosa dapat dilakukan dengan cara membandingkan faktor-faktor gejala yang timbul antar faktor gejala yang satu dengan faktor gejala yang lainnya, sehingga akan menghasilkan diagnosa yang sesuai dengan gejala yang ditimbulkan supaya tidak ada kesalahan dalam menangani permasalahan penanggulangan gizi buruk pada ibu hamil.

Untuk itu, peneliti akan merancang suatu sistem pendukung keputusan dimana sistem tersebut di rancang untuk mempermudah bidan dan kader posyandu dalam mendiagnosa gizi buruk ibu hamil. Berdasarkan latar belakang di atas peneliti mengangkat judul "Sistem Pendukung Keputusan Untuk Mendiagnosa Gizi Buruk Ibu Hamil Menggunakan Metode Ahp". Tujuan dai penelitian ini adalah untuk mempermudah posyandu dalam proses mendiagnosa gizi buruk ibu hamil sehingga mempermudah kinerja dalam mendiagnosa lebih efektif.

\section{METODOLOGI PENELITIAN}

\subsection{Giji Buruk}

Malnutrisi yaitu gizi buruk atau Kurang Energi Protein (KEP) dan defisiensi mikronutrien merupakan maslah yang membutuhkan perhatian khusus terutama di negara-negara berkembang, yang merupakan faktor risiko penting terjadinya kesakitan dan kematian pada ibu hamil dan balita(Diah Krisnansari, 2010).

Gizi buruk tidak hanya meningkatkan angka kesakitan dan angka kematian tetapi juga menurunkan produktifitas, menghambat pertumbuhan sel-sel otak yang mengakibatkan kebodohan dan keterbelakangan. Masalah-masalah yang ditimbulkan akibat gizi buruk yaitu bayi lahir dengan berat badan rendah, bayi kekurangan zat besi dapat merusak gangguan sel-sel otak yang di kemudian hari dapat berpengaruh pada kecerdasan anak. Gizi buruk berdampak ke berbagai macam penyebab, seperti rendahnya tingkat pendidikan, kemiskinan, pola makan, pola hidup, transportasi, sosial budaya dan sebagainya. Masalah gizi buruk tidak dapat diselesaikan oleh sektor kesehatan, maka dari itu pencegahan gejala gizi buruk sangat diharapkan sejak semula agar tidak menimbulkan masalah di kemudian hari.

\subsection{Sistem Pendukung Keputusan}

Sistem Pendukung Keputusan (SPK) adalah bagian dari sistem informasi berbasis komputer termasuk sistem berbasis pengetahuan atau manajemen pengetahuan yang dipakai untuk mendukung pengambilan keputusan dalam suatu organisasi atau perusahaan (Syawaluddin Purba, 2015). Sistem Pendukung Keputusan (SPK) bukan merupakan alat pengambilaan keputusan, melainkan merupakan sistem yang membantu pengambil keputusan untuk melengkapi informasi dari data yang telah diolah secara relevan dan diperlukan untuk membuat keputusan tentang suatu masalah dengan lebih cepat dan akurat (Syawaluddin Purba, 2015) 


\subsection{Konsep Dasar AHP (Analytic Hierarchy Process)}

AHP (Analytic Hierarchy Process) adalah suatu teori umum tentang pengukuran yang digunakan untuk menemukan skala rasio, baik dari perbandingan berpasangan yang diskrit maupun kontinyu (Eko Darmanto,dkk, 2014).

AHP menguraikan masalah multi faktor atau multi kriteria yang kompleksmenjadi suatu hirarki. Hirarki didefinisikan sebagai suatu representasi dari sebuah permasalahan yang kompleks dalam suatu struktur multi level dimana level pertama adalah tujuan, diikuti level faktor, kriteria, sub kriteria, dan seterusnya ke bawah hingga level terakhir dari alternatif (Eko Darmanto,dkk, 2014).

\subsubsection{Prinsip Dasar AHP}

Dalam menyelesaikan permasalahan dengan AHP ada beberapa prinsip yang harus dipahami (Kusrini, 2007), diantaranya adalah:

a. Membuat hierarki

b. Sistem yang kompleks bisa dipahami dengan memecahnya menjadi elemenelemen pendukung, menyusun elemen secara hierarki, dan menggabungkannya atau mensintesisnya.

c. Penilaian kriteria dan alternatif Kriteria dan alternatif dilakukan dengan perbandingan berpasangan.

d. Menurut Saaty (1988), untuk berbagi persoalan, skala 1 sampai 9 adalah skala terbaik untuk mengekspresikan pendapat. Nilai dan definisi pendapat kualitatif dari skala perbandingan Saaty bisa diukur menggunakan tabel analisis.

\subsubsection{Prosedur AHP}

Pada dasarnya, prosedur AHP (Kusrini, 2007), meliputi:

a. Mendefinisikan masalah dan menentukan solusi yang diinginkan, lalu menyusun hierarki dari permasalahan yang dihadapi. Penyusunan hierarki adalah dengan menetapkan tujuan yang merupakan sasaran sistem secara keseluruhan pada level teratas.

b. Menentukan prioritas elemen

1. Langkah pertama adalah menentukan prioritas elemen adalah membuat perbandingan pasangan, yaitu membandingkan elemen secara berpasangan sesuai kriteria yang diberikan.

2. Matriks perbandingan berpasangan diisi menggunakan bilangan untuk mempresentasikan kepentingan relatif dari suatu elemen terhadap elemen yang lainnya.

c. Sintesis

Pertimbangan-pertimbangan terhadap perbandingan berpasangan disintesis untuk memperoleh keseluruhan prioritas. Hal-hal yang dilakukan dalam langkah ini adalah:

1. Menjumlahkan nilai-nilai dari setiap kolom pada matriks.

2. Membagi setiap nilai dari kolom dengan total kolom yang bersangkutan untuk memperoleh normalisasi matriks. 
3. Menjumlahkan nilai-nilai dari setiap baris dan membaginya dengan jumlah elemen untuk mendapatkan nilai rata-rata.

4. Mengukur Konsistensi dalam pembuatan keputusan, penting untuk mengetahui seberapa baik konsisten yang ada karena kita tidak menginginkan keputusan berdasarkan pertimbangan dengan konsistensi yang rendah. Hal-hal yang dilakukan dalam langkah ini adalah:

5. Kalikan setiap nilai kolom pertama dengan prioritas relatif elemen pertama, nilai pada kolom kedua dengan prioritas relatif elemen kedua, dan seterusnya.

6. Jumlahkan setiap baris.

7. Hasil dari perjumlahan baris dibagi dengan elemen prioritas relatif yang bersangkutan.

8. Jumlahkan hasil bagi diatas dengan banyaknya elemen yang ada, hasilnya disebut $\lambda$ maks.

9. Hitung Consistency Index (CI) dengan rumus :

$C I=(\lambda \operatorname{maks}-n) / n$

Keterangan:

$\mathrm{n}$ = banyaknya elemen

10. Hitung Rasio Konsistensi/ConsistencyRatio (CR) dengan rumus :

$$
C R=C I / R C
$$

$$
\begin{aligned}
& \text { Keterangan: } \\
& \text { CR = Consistency Ratio } \\
& \text { CI = Consistency Index }
\end{aligned}
$$

11. Memeriksa konsistensi hierarki. Jika nilainya lebih dari $10 \%$, maka penilaian data judgment harus diperbaiki. Namun jika rasio konsistensi (CR/IR) kurang atau samadengan 0,1, maka hasil perhitungan bisa dinyatakan benar. Daftar Indeks Random Konsistensi (IR) bisa dilihat dari Tabel berikut:

\subsection{Java}

Java adalah bahasa pemrogaman yang dirancang tidak tergantung kepada platform alias platfrom independent, sehingga program yang ditulis di bahasa pemrograman java idealnya harus bisa dijalankan disemua sistem operasi(Tim EMS, 2015:5). Semua jenis komputer yang digunakan baik menggunakan sistem operasi Windows, Linux, Mac OS dan sebagainya tetap bisa dijalankan satu program yang sama. 


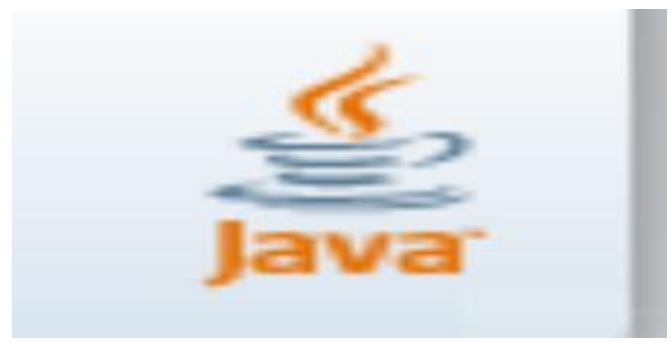

Gambar 1. Tampilan Java

\subsection{Xampp}

Xampp adalah perangkat lunak (free software) bebas, yang mendukung untuk banyak sistem operasi, yang merupakan kompilasi dari beberapa program (Opray Winter, 2014). Fungsi Xampp yaitu sebagai server yang berdiri sendiri (localhost), yang terdiri dari banyak program, diantaranya :

a. Apache HTTP Server

b. MySQL Database

c. PHP dan Perl

MySQL adalah sebuah perangkat lunak sistem manajemen basis data SQL (database management system) atau DBMS yang multithread, multi-user, dengan sekitar 6 juta instalasi di seluruh dunia (Opray Winter, 2014)

Metode penelitian yang digunakan dalam penelitian ini adalah model sekuensial linier. Sekuensial Linier merupakan perkembangan model klasik dari model waterfall yaitu model pengembangan siklus hidup yang terdiri dari tahapan perencanaan sistem (rekayasa sistem), analisa kebutuhan, desain, penulisan program, pengujian dan perawatan sistem.

\section{HASIL DAN PEMBAHASAN}

Algoritma adalah susunan yang logis dan sistematis untuk memecahkan suatu masalah atau untuk mencapai tujuan tertentu. AHP adalah metode algoritma pengambilan keputusan untuk permasalahn multikriteria (Multi Crtiria Decision Making atau MCDM). Permasalahan multikriteria dalam AHP disederhanakan dalam bentuk hierarki yang terdiri dari 3 komponen utama. Yaitu tujuan atau goal dari pengambilan keputusan, criteria penilaian dan alternative pilihan. Adapun gambar dari hierarki tersebut adalah sebagai berikut:

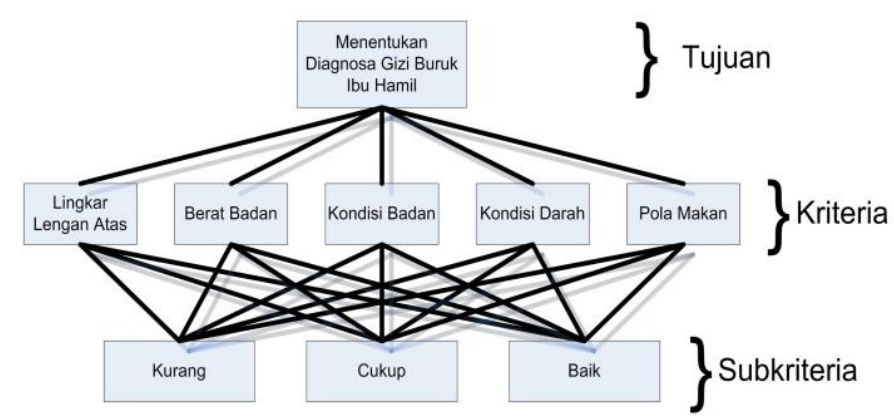

Gambar 2. Rancangan Decission Hierarchy 
Setelah permasalahan multikriteria dimodelkan dalam hierarki seperti gambar diatas, selanjutnya untuk menyelesaikan kasus yang dihadapi maka dibuat hierarki permasalahannya terlebih dahulu. Dimana tujuan atau goal adalah Menentukan Diagnosa Gizi Buruk Ibu Hamil. Kriteria lingkar lengan atas, berat badan, kondisi badan, kondisi darah, pola makan dengan subkriteria kurang, cukup, baik. Dan alternative pilihan yang digunakan yaitu nama-nama ibu hamil yang akan diinputkan ke dalam program nantinya. Berikut ini hierarki yang di dapat melalui 3 komponen tersebut.

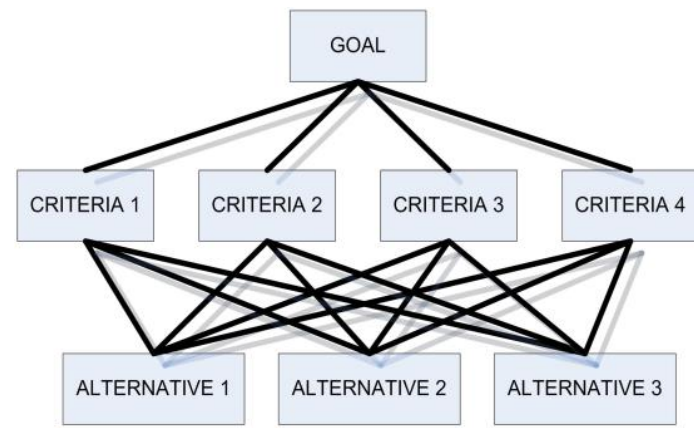

Gambar 3. Rancangan Analytical Hierarchy Process

Tabel 1. Perhitungan

\begin{tabular}{|l|c|c|c|}
\hline & Jumlah Per Baris & Prioritas & Hasil \\
\hline LLA & 2.53 & 0.48 & 3.01 \\
\hline BB & 1.38 & 0.26 & 1.64 \\
\hline KB & 0.65 & 0.13 & 0.77 \\
\hline KD & 0.41 & 0.08 & 0.49 \\
\hline PM & 0.25 & 0.5 & 0.30 \\
\hline
\end{tabular}

Tabel 2. Nilai Akhir

\begin{tabular}{|c|c|c|c|c|c|c|c|}
\hline & LLA & BB & KB & KD & PM & Jumlah & $\begin{array}{c}\text { Bilangan } \\
\text { Bulat }\end{array}$ \\
\hline A & $0.48^{*} 0.13=$ & $0.26 * 0.53=$ & $0.13 * 0.22=$ & $0.08 * 0.46=$ & $0.05 * 0.30=$ & 0.29 & 29 \\
0.06 & 0.14 & 0.03 & 0.04 & 0.02 & & \\
\hline B & $0.48 * 1=$ & $0.26 * 1=$ & $0.13 * 0.57=$ & $0.08 * 0.22=$ & $0.05 * 0.55=$ & 0.88 & 88 \\
& 0.48 & 0.26 & 0.07 & 0.04 & 0.03 & & \\
\hline C & $0.48^{*} 0.36=$ & $0.26 * 0.19=$ & $0.13 * 0.22=$ & $0.08 * 0.46=$ & $0.05 * 0.55=$ & 0.32 & 32 \\
& 0.17 & 0.05 & 0.03 & 0.04 & 0.03 & & \\
\hline D & $0.48^{*} 0.36=$ & $0.26 * 1=$ & $0.13 * 0.57=$ & $0.08 * 0.46=$ & $0.05 * 0.55=$ & 0.53 & 53 \\
0.17 & 0.26 & 0.03 & 0.04 & 0.03 & & \\
\hline
\end{tabular}




\section{KESIMPULAN}

Berdasarkan hasil penelitian dan pengamatan dapat diambil beberapa kesimpulan, antara lain :

a. Proses awal pembuatan sistem ini, terlebih dahulu melakukan pengamatan dan mempelajari sistem yang sedang berjalan, mencari permasalahan yang ada, kemudian mencari solusi untuk menyelesaikan permasalahan yang ditemukan, kemudian merancang dan mengaplikasikannya ke dalam bentuk program sehingga dapat digunakan dengan mudah.

b. Sistem yang baru akan membantu dan mempermudah kinerja kader dalam melakukan pengolahan data, baik menyimpan data, mengubah data, menghapus data dan menghasilkan informasi lapan saja informasi itu dibutuhkan.

\section{DAFTAR PUSTAKA}

[1] Diah Krisnansari., " Nutrisi Dan Gizi Buruk"., Mandala of Health. Volume 4, Nomor 1, Januari 2010.

[2] Eko Darmanto, Dkk., "Penerapan Metode Ahp (Analythic Hierarchy Process) Untuk Menentukan Kualitas Gula Tumbu"., Jurnal Simetris., Volume 5 Nomor 1., 2014.

[3] syawalludinPurba,2015.http://simple25life.blogspot.com/2015/pengertian-dan-fungsisistem-pendukung.s

[4] Kusrini, M.kom, “Konsep dan Aplikasi Sistem Pendukung Keputusan”, Andi, Yogyakarta, 2007

[5] TIM EMS, "Teori Dan Praktik PHP-MySQL Untuk Pemula", 2015 